EPJ Web of Conferences 29, 00029 (2012)

DOI: $10.1051 /$ epjconf/20122900029

(C) Owned by the authors, published by EDP Sciences, 2012

\title{
Realization of tin oxide like anode for the manufacture of the organic solar cells
}

\author{
A. Mohammed-Krarroubi ${ }^{1}$, F. Z. Dahou ${ }^{\text {a }}{ }^{1}$, L. Barkat ${ }^{1}$, J. C. Bernede ${ }^{2}$ et A. Khelil ${ }^{1}$ \\ ${ }^{1}$ Physics laboratory of the Thin Layers and Materials for Electronics LPCMME, Department of \\ Physics, University of Oran. Algeria. \\ ${ }^{2}$ Physics laboratory of the solids for Electronics LAMP, Université de Nantes, Nantes-Atlantique, \\ Faculté des Sciences et des Techniques, 2 rue de la Houssinière, BP 92208, 44000 Nantes, France
}

\begin{abstract}
The transparent oxides such as $\mathrm{SnO}_{2}, \mathrm{In}_{2} \mathrm{O}_{3}$ and $\mathrm{ZnO}$ continue to arouse a private interest for their various applications. The objective of the various studies being to carry out the layers which are simultaneously most transparent and most conducting possible. Thus in the field of the solar spectrum, the transmission of the layers must be higher than $80 \%$ and their conductivity exceeding $10^{3}(\mathrm{Ohm} . \mathrm{cm})^{-1}$. Their transparency which is related to the value of their forbidden band must be higher than $3.7 \mathrm{e} \mathrm{V}$. Their electric properties as for them depend on the composition of the layers and a possible doping. In this work, one characterized layers of $\mathrm{SnO}_{2}$ deposited by chemical pulverization, one carried out measurements by, electronic scan microscopy, diffraction of x-rays and also of the optical measurements and electronic. It results from it that the layers are conducting and transparent in the visible one but they are relatively rough, following its characterizations, one carried out organic photovoltaic cells using these layers of $\mathrm{SnO}_{2}$ and also of the commercial ITO like anode in these components. More particularly one was interested in the influence of the presence of a fine layer of gold between the anode and organic material.
\end{abstract}

\section{Introduction}

Transparent conducting electrodes are now often used in different devices such as flat panel, organic light emitting diodes, solar cells and also smart windows. The oxides used to obtain such transparent conductive films are indium oxide, tin oxide $\left(\mathrm{SnO}_{2}\right)$, indium tin oxide (ITO), $\mathrm{ZnO}$ [1], all these films aren-type semiconductors. $\mathrm{SnO}_{2}$ is one of these oxides and last years, a growing interest has been devoted to tin oxide thin films [2-3]. Due to its high chemical stability, as well as optical magnetic and electrical properties, $\mathrm{SnO}_{2}$ has a wide range of applications such as films for electro chromic devices [4], organic light emitting diodes [3], chemical sensors [5], $n-p$ junction electrodes in dye sensitized solar cells [6]. As shown recently $\mathrm{SnO}_{2}$ appears to be one of the more promising anodic electro chromic materials [7]. Several methods have been used to prepare tin oxide thin films such as sputtering [8,9,10-11], electron beam evaporation [12], sol gel

\footnotetext{
${ }^{a}$ e-mail : fatima_dahou@yahoo.fr
}

This is an Open Access article distributed under the terms of the Creative Commons Attribution License 2.0, which permits unrestricted use, distribution, and reproduction in any medium, provided the original work is properly cited. 
[13], dip coating, spin coating, electro deposition [14], chemical bath deposition [15,16,17] and also spray pyrolysis [15,18-19]. It has been shown that $\mathrm{SnO}_{2}$ films with good electronic properties can be achieved by spray pyrolysis depending on growing parameters such as precursor concentration [19] and substrate temperature [20].Smart windows, dye sensitized solar cells need, for economical reason, cheap deposition technique. In the case of n-type transparent conductive oxides a "perfume atomizer" available in cosmetic shop has been used with success [21, 22]. Therefore, this very simple technique is used in the present work to grow $\mathrm{SnO}_{2}$ thin films. A comparison between the properties of the $\mathrm{SnO}_{2}$ films obtained with a perfume atomizer to those of $\mathrm{SnO}_{2}$ films achieved with a more classical spray apparatus [23] allow us to prove that perfume atomizer is useful to obtain $\mathrm{SnO}_{2}$ thin films with expected properties.

\section{Experimental}

The substrates used were bare glasses. Before deposition, the substrates were cleaned by acetone for eliminating any greasy track and then they were cleaned with soap and abundantly rinsed with distilled water. Finally, they were dried by a nitrogen flow. The substrate temperature during the deposition was around $350^{\circ} \mathrm{C}$. This temperature has been shown to be efficient to achieve $\mathrm{SnO}_{2}$ films [15]. Tin chloride hexahydrate $\left(\mathrm{SnCl}_{2} ; 6 \mathrm{H}_{2} \mathrm{O}\right)$ was chosen as precursor, it was dissolved in bi-distilled water. The effect of solution molarity on the $\mathrm{SnO}_{2}$ thin films properties was studied $(0.2-0.45 \mathrm{M})$. These molarities have been chosen because we have shown in a previous paper [23] that there is a threshold value for the different film properties when the precursor concentration varies between $0.2 \mathrm{M}$ and $0.3 \mathrm{M}$. The solution was sprayed manically in air with the use of a perfume atomizer. This technique has some advantages such as an atomization based on hydraulic pressure without using any carrier gas, intermittent spraying and fine atomization. As a matter of fact during spray deposition shot, the substrate temperature was reduced from $350{ }^{\circ} \mathrm{C}$ to $330-340$ ${ }^{\circ} \mathrm{C}$. Therefore the spraying process was stopped during the time necessary to recover $350{ }^{\circ} \mathrm{C}$ as substrate temperature.

Such conditions are complete when a shot is followed by $5 \mathrm{~s}$ of rest. The volume of the solution for each deposition was $100 \mathrm{ml}$ (except in the case of $0.3 \mathrm{M}$ where $200 \mathrm{ml}$ was also used). Only a small amount of the solution was consumed in each shot and 45 min was necessary for $100 \mathrm{ml}$. The substrate to nozzle distance was $30 \mathrm{~cm}$.

A Siemens D-500 X-ray diffractometer using the $\mathrm{Cu} \mathrm{Ka}$ radiation was employed to study the film structure.

It has been shown that electro chromic, but also dyes sensitized solar cells performances are related to the grain size of the films, because a small grain size implies a large surface to bulk ratio. Crystallite size can be estimated from the full width at half maximum (FWHM) of the X-ray diffraction liner. The broadening of the FWHM is inversely proportional to the average crystallite size (D) as predicted by the well-known Scherer's formula [24] the grain size D is:

$$
\mathrm{D}=\mathrm{K} \lambda / \beta \cos \theta
$$

Where $\beta$ is the observed angular width at half maximum intensity of the peak with: $\beta^{2}=\beta^{, 2}-\beta_{0}{ }^{2}$

Where $\beta^{\prime}$ is the measured line width at half maximum and $\beta_{0}$ is the instrumental broadening [24]. $\beta_{0}=0.16$ with the apparatus used. $K$ is dimension less number, which is equal to 0.9. $\lambda$ is the $\mathrm{X}$-ray wavelength $(0.1548 \mathrm{~nm}$ for $\mathrm{Cu} \mathrm{K} \alpha 1)$ and $\theta$ is the diffraction angle.

The surface topography and the cross-section of the films were observed with a field emission scanning electron microscope (SEM, JEOL F-6400). Using simple software, the thickness of the films was measured from the cross-section visualization.

Electron probe microanalysis (EPMA) was performed using a JEOL F-5800 LV, SEM equipped with a PGT X-ray microanalysis system; X-rays were detected by a germanium crystal.

The optical measurements were carried out at room temperature using a Carry spectrometer. The optical density was measured at wavelengths of $2-0.25 \mu \mathrm{m}$. The majority carrier type has 
been checked by the hot probe technique. A n-type constantan wire was used as the reference sample. The electrical conductivity, at room temperature, was measured using gold electrodes.

\section{Results}

The XRD patterns were recorded for different films deposited onto glass substrate, the solution molarity varying from $0.2 \mathrm{M}$ to $0.45 \mathrm{M}$. All the peaks visible belong to the cubic $\mathrm{SnO}_{2}$ phase (JCPDS 04-835). Only peaks corresponding the (lll 111$),\left(\begin{array}{lll}2 & 0 & 0\end{array}\right),\left(\begin{array}{lll}2 & 2 & 0\end{array}\right)$ and $\left(\begin{array}{lll}2 & 2 & 2\end{array}\right)$ directions are visible, there is not $\mathrm{SnCl}_{2} ; 6 \mathrm{H}_{2} \mathrm{O}$ contribution in the XRD diffractograms (Figure 1).

In randomly oriented powder, the most intense XRD peak is corresponding to the $\left(\begin{array}{lll}2 & 0 & 0\end{array}\right)$ direction. It can be seen in Figure. 1 that in the present diffractograms, the peak along the (hhh) direction is the strongest. It can be concluded that crystallites are mainly oriented along the (hhh) direction. The degree of preferential orientation along this (hhh) direction $\mathrm{F}_{\mathrm{hhh}}$ has been estimated using [25]:

$$
\mathrm{F}_{\text {hhh }}=\sum_{\mathrm{h}=1.2} \mathrm{f}_{(\mathrm{hhh})}=\left[\sum_{=1.2} \mathrm{I}_{(\mathrm{hhh}) / \mathrm{I}_{0(\mathrm{hhh})}}\right] /\left[\sum_{\mathrm{hkl}} \mathrm{I}_{(\mathrm{hkl})} / \mathrm{I}_{0(\mathrm{hkl})}\right]
$$

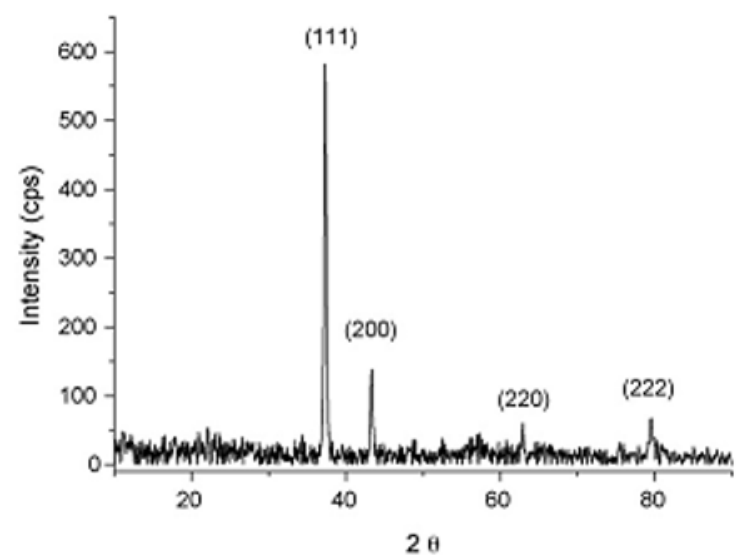

Fig.1. Typical X-ray diffraction diagram of a $\mathrm{SnO}_{2}$ film, deposited from a precursor molarity of 0.35 $\mathrm{M}$ (solution volume $100 \mathrm{ml}$ ).

Table 1. Degree of preferential orientation $F_{\text {hhh }}$ and D grain size deduced from XRD measurements and MEB visualization

\begin{tabular}{lllllll}
\hline \multicolumn{7}{l}{ Precursor concentration } \\
& $0.2 \mathrm{M}$ & $0.3 \mathrm{M}$ & $0.3 \mathrm{M}(200 \mathrm{ml})$ & $0.35 \mathrm{M}$ & $0.4 \mathrm{M}$ & $0.45 \mathrm{M}$ \\
$\mathrm{D}_{\text {XRD }}(\mathrm{nm})$ & 28 & 26 & 32.5 & 28 & 25 & 25 \\
$\mathrm{~F}_{\text {hhh }}(\%)$ & 82 & 84 & 87 & 83 & 87 & 84 \\
$\mathrm{D}_{\text {SEM }}(\mathrm{nm})$ & 34 & 35.5 & 44.5 & 37 & 36 & 36.5 \\
\hline
\end{tabular}

Where $\mathrm{I}_{\mathrm{hkl}}$ is the intensity of the (hkl) line for the thin films and $\mathrm{I}_{0(\mathrm{hkl})}$ the intensity of the (hkl) line for randomly orientated sample according to the Joint Committee on Powder Diffraction Standards (JCPDS) data. The results are presented in Table 1. It can be seen that the crystallites are oriented along (hhh) direction. Moreover, it can be seen that the Fhh value, which is around $85 \%$, does not vary with the precursor concentration. The mean value of the grain size $\mathrm{D}$, deduced from Eq. (1), also does not vary significantly with the precursor solution concentration; the values are around $27 \mathrm{~nm}$. 
Typical surface of films is visualized in Figure2, while a cross section is shown in Figure 3.With a small magnification; it can be seen in Fig. 2a that, if the surface of the films appears rough, neither hole, nor cracks are visible. For large magnification (Fig. 2b), small grains round shaped are clearly visible. Their diameter, estimated statistically, is around $35 \mathrm{~nm}$ (Table 1). The averaged values of the grain size has been estimated from SEM statistic (Table 1)

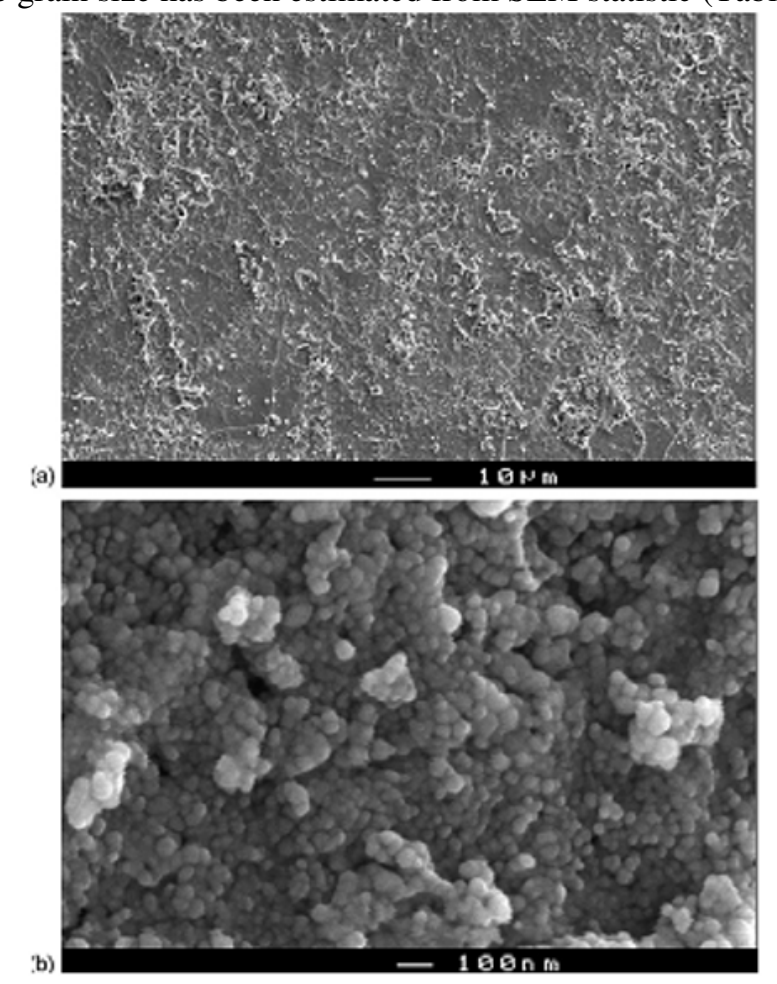

Fig.2. Microphotographs of $\mathrm{SnO}_{2}$ films, deposited from a precursor molarity $0.35 \mathrm{M}$ (solution volume $100 \mathrm{ml}$ ): (a) small magnification and (b) large magnification

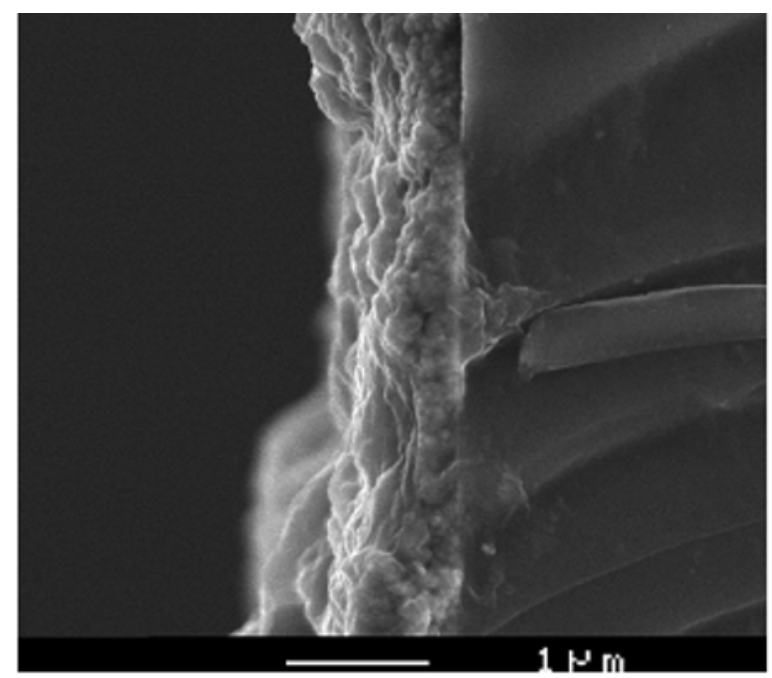

Fig. 3. Cross-section visualization of $\mathrm{SnO}_{2}$ film from a precursor concentration of $0.45 \mathrm{M}$. 
Measurements are slightly higher than those estimated from XRD measurements: the two techniques are different, the former allows measuring the size of the grain visualized, and the latter allows estimating the coherent crystalline thickness.

Therefore, since the difference between the grain size visualized and the coherent crystalline thickness are not very different, it can be concluded that there is not many nanocrystals in each grain.

The films are, as expected, porous. The cross-section in Figure 3 confirms that the films are porous. It can be seen in Table 2 that the film thickness $t$ increases slightly with the precursor concentration $\mathrm{c}, \mathrm{t}=230 \mathrm{~nm}$ when $\mathrm{c}=0.2 \mathrm{M}$ up to $\mathrm{t}=300 \mathrm{~nm}$ when $\mathrm{c}=0.4$ Mand then it increases abruptly, $\mathrm{t}=1000 \mathrm{~nm}$ with $\mathrm{c}=0.45 \mathrm{M}$. Therefore, there is a threshold value between $0.4 \mathrm{M}$ and $0.45 \mathrm{M}$. It should be noted that, when the volume of the precursor solution is double, the thickness is nearly double.

The EPMA analysis results are reported in Table 2. The films are nearly storchiometrics, whatever the concentration $\mathrm{c}$ of the precursor. Moreover, some chlorine (1.5 0.5 at. \%) is present in the films. It is issued from the precursor $\mathrm{SnCl}_{2} 6 \mathrm{H}_{2} \mathrm{O}$, but $\mathrm{Cl}$ atomic concentration stays quite small.

A typical spectral absorbance of film obtained from a precursor concentration $0.4 \mathrm{M}$ is reported in Figure 4.

Table 2. Film thickness and composition deduced from SEM and EPMA studies

\begin{tabular}{lllllll}
\hline \multicolumn{5}{c}{ Precursor concentration } & & \\
& $0.2 \mathrm{M}$ & $0.3 \mathrm{M}$ & $0.3 \mathrm{M}(200 \mathrm{ml})$ & $0.35 \mathrm{M}$ & $0.4 \mathrm{M}$ & $0.45 \mathrm{M}$ \\
Thickness (nm) & 230 & 230 & 520 & 270 & 300 & 1000 \\
$\%$ atomic & & & & & & \\
$\mathrm{Sn}$ & 48 & 49 & 50.5 & 50.5 & 49 & 47.5 \\
$\mathrm{O}_{2}$ & 50.5 & 50 & 48 & 48 & 50 & 50.5 \\
$\mathrm{Cl}$ & 1.5 & 1 & 1.5 & 1.5 & 1 & 2 \\
\hline
\end{tabular}

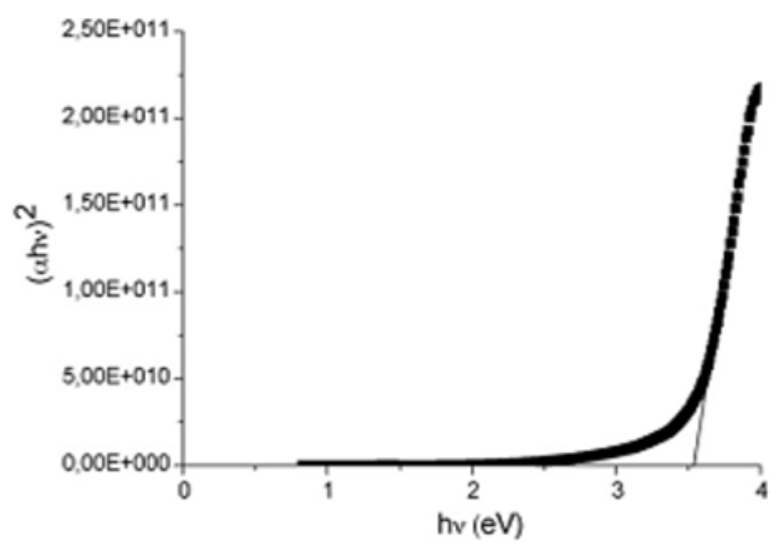

Fig. 4. (ahn) $)^{2}$ vs. hn for a $\mathrm{SnO}_{2}$ film from a precursor concentration of $0.4 \mathrm{M}$ 
If all the films exhibit the cubic $\mathrm{SnO}_{2}$ phase, the influence of $\mathrm{c}$ on film properties depends on the deposition technique used (Table 4). In the case of small precursor concentration, all the films exhibit preferential orientation along the $\left(\begin{array}{lll}1 & 1 & 1\end{array}\right)$ direction, the grain size is around $30 \mathrm{~nm}$, the thickness of about $0.3 \mathrm{~mm}$, the films are nearly storchiometric with a resistivity of about $10^{3} \Omega \mathrm{cm}$. However, the evolution of these properties when c increases, depends strongly on the spraying technique used. In the case of "classical spray" we have shown [26] that the $\mathrm{SnO}_{2}$ film properties depend strongly on the tin concentration. There is a threshold value for the different film properties when the precursor solution molarity varies between $\mathrm{c}=0.2 \mathrm{M}$ and $0.3 \mathrm{M}$. In that case, there is a strong increase of the thickness of the film, the oxygen concentration present in the $\mathrm{SnO}_{2 \mathrm{x}}$ films decreases from 1 to 0.86 , the film texturation is modified (Table 4). It can be seen that when a perfume atomizer is used the threshold value is shifted toward higher solution molarity. As a matter of fact, the new threshold value appears between $\mathrm{c}=0.4 \mathrm{M}$ and $0.45 \mathrm{M}$.

Table 3. Electrical characterisation

\begin{tabular}{llllllll}
\hline \multicolumn{7}{c}{$\begin{array}{l}\text { Precursor } \\
\text { concentration }\end{array}$} & \\
& $0.2 \mathrm{M}$ & $0.3 \mathrm{M}$ & $\begin{array}{l}0.3 \\
(200 \mathrm{ml})\end{array}$ & $\mathrm{M}$ & $0.35 \mathrm{M}$ & $0.4 \mathrm{M}$ & $0.45 \mathrm{M}$ \\
\hline $\begin{array}{l}\text { Room temperature resistivity } \\
\mathrm{X} 10^{3} \Omega \mathrm{cm}\end{array}$ & 0.32 & 0.66 & 1.28 & 1.47 & 1.17 & 8.9 \\
\hline
\end{tabular}

Table 4. Comparison of structural; chemical and electrical proprieties of $\mathrm{SnO}_{2}$ films

\begin{tabular}{llllllll}
\hline $\begin{array}{l}\text { Spray } \\
\text { pyrolysis } \\
\text { technique }\end{array}$ & $\begin{array}{l}\text { Precursor } \\
\text { concentration }(\mathrm{M})\end{array}$ & $\begin{array}{l}\mathrm{F}_{111} \\
(\%)\end{array}$ & $\begin{array}{l}\mathrm{D} \\
(\mathrm{nm})\end{array}$ & $\begin{array}{l}\text { Thickness } \\
(\mu \mathrm{m})\end{array}$ & $\begin{array}{l}\mathrm{Si} \\
\text { at/O at }\end{array}$ & $\begin{array}{l}\text { Majority } \\
\text { carrier }\end{array}$ & $\begin{array}{l}\text { Room } \\
\text { temperature } \\
\text { resistivity } \\
\mathrm{x} 10^{3} \Omega \mathrm{cm}\end{array}$ \\
\hline Nozzle & Up to 0.2 & $\approx 80$ & $30-40$ & $0.3-0.4$ & $\approx 1$ & 1 \\
& Above 0.3 & $\approx 15$ & & 3 & $\approx 0.85$ & $\mathrm{n}$ & 5 \\
$\begin{array}{l}\text { Perfume } \\
\text { atomizer }\end{array}$ & Up to 0.4 & $\approx 85$ & $25-$ & $0.23-0.3$ & $\approx 1$ & $\approx 1$ \\
& 0.45 & & 325 & & & $\approx 9$ \\
\hline
\end{tabular}

The precursor concentration is used as parameter deposited by spray equipped with a classical nozzle and with a perfume atomizer with a strong increase in film thickness and resistivity values (Table 4). This different behavior should be discussed. During spray pyrolysis of $\mathrm{SnCl}_{2} 6 \mathrm{H}_{2} \mathrm{O}$ the reaction process corresponds to a heat decomposition of tin chloride to tin oxide in the presence of water and air oxygen. The deposited films may have disordered $\mathrm{Sn}(\mathrm{OH})_{2}$ structure or crystalline $\mathrm{SnO}_{2}$ structure according to the following reactions [20]:

$$
\begin{aligned}
& \mathrm{SnCl}_{2}+2 \mathrm{H}_{2} \mathrm{O} \text { Ts } \longrightarrow 2 \mathrm{HCl}+\mathrm{Sn}(\mathrm{OH})_{2} \\
& \mathrm{SnCl}_{2}+2 \mathrm{H}_{2} \mathrm{O} \text { Ts } \longrightarrow 2 \mathrm{HCl}+\mathrm{SnO}_{2}+\mathrm{OH}
\end{aligned}
$$

If some tin hydroxide is present in the films, it cannot be put in evidence by XRD since it should be amorphous [20].

However, Kamal et al. [20] have shown that the formation of $\mathrm{Sn}(\mathrm{OH})_{2}$ is more probable at higher substrate temperature $\left(420^{\circ} \mathrm{C}\right)$ than the one used in the present work $\left(350^{\circ} \mathrm{C}\right)$.

Moreover, while there are two oxygen atoms in tin hydroxide for one in tin oxide, there is no significant increase of the relative atomic concentration of oxygen in the $0.45 \mathrm{M}$ films (Table 2). All this means that the threshold concentrations are probably not determined by tin hydroxide formation. In spray pyrolysis, the growth rate of the films increases with the solution concentration. Hence, at the quite small pyrolysis temperature used, the efficiency of 
rearrangement of the arriving material is small and the porosity of the films increases with solution concentration, which justifies the increase of thickness and resistivity.

That means that after micro particles land on the film surface, decomposition of chlorides and desorption of chlorine and material rearrangement should take place. The intermittent spraying may promote this process by placing intervals between repeated depositions, which justifies the shift towards higher solution molarity of the threshold value discussed above, while in the case of classical spray the pyrolysis reaction is not completed when c increases above $0.3 \mathrm{M}$.

\section{Conclusion}

We have shown that a perfume atomizer can be used for the deposition of tin oxide thin films by spray pyrolysis. It allows high quality films growth at relatively low temperature $\left(350{ }^{\circ} \mathrm{C}\right)$. The study of the influence of precursor concentration on the $\mathrm{SnO}_{2}$ thin films properties show that the key element is the intermittent spraying using a perfume atomizer. The pyrolysis reaction can be achieved for higher solution molarity by comparison with classical spray process. The films are in high crystalline quality with the $\left(\begin{array}{lll}1 & 1 & 1\end{array}\right)$ preferred orientation. The averaged grain size is around $25-30 \mathrm{~nm}$. The films are nearly storchiometrics; their resistivity is around $10^{3} \Omega \mathrm{cm}$. The whole properties of the films grain using perfume atomizer are qualitatively as good that measured on film deposited by classical spray pyrolysis technique.

\section{References}

1. K. L. Chopra, S. Major, D. K. Pandya, Thin Solid Films 1021 (1983).

2. J. He, H. Lindstrom, A. Hagfeldt, S. E. Lindquist, J. Phys. Chem. B 1038940 (1999).

3. I. M. Chan, F. C. Hong, Thin Solid Films 450304 (2004).

4. M. Kitao, K. Izawa, K. Urabe, T. Komatsu, S. Kuwano, S. Yamada, Jpn. J. Appl. Phys. 33 6656 (1994).

5. H. Kumagai, M. Matsumoto, K. Toyoda, M. Obava, J. Mater. Sci. Lett. 151081 (1996).

6. J. Bandara, C. M. Divarathne, S. D. Nanayakkara, Solar Energy Mater. Solar Cells 81429 (2004).

7. E. Avendan o, L. Berggren, G. A. Niklasson, C. G. Granquist, A. Azens, Thin Solid Films 49630 (2006).

8. Y. M. Lu, W. S. Hwang, J. S. Yang, Surf. Coat. Technol. 155231 (2002).

9. I. Hotovy, J. Huran, L. Spiess, J. Liday, H. Sitter, S. Hascik, Vacuum 691 (2003) 237.

10. D. A. Wruck, A. M. Dixon, M. Rubin, S. N. Bogy, J. Vac. Sci. Technol. 192170 (1991).

11. J. L. Yang, Y. S. Lai, J. S. Chen, Thin Solid Films 488242 (2005).

12. T. Seike, J. Nagai, Solar Energy Mater. 22107 (1991).

13. L. Wang, Z. Zhong, Y. Cao, J. Ceram. Soc. Jpn. 101227 (1993).

14. F. Vera, R. Schrebler, E. Mun oz, C. Suarez, P. Cury, A. Gomez, R. Cordova, R. E. Marotti, E. A. Dalchiele, Thin Solid Films 490182 (2005).

15. L. Barkat, L. Cattin, A. Reguig, M. Regragui, J. C. Berne`de, Mater. Chem. Phys. 89 11-20 (2005).

16. M. Ristova, J. Velveska, M. Ristov, Solar Energy Mater. Solar Cells 71219 (2002).

17. B. Pejova, T. Kocareva, M. Najdoski, I. Grosdanov, Appl. Surf. Sci. 165271 (2000).

18. X. Yi, W. Wenzhong, Q. Yitai, Y. Li, L. Zhiwen, J. Crystal Growth 1656 (1996).

19. H. Kamal, E. K. Elmaghraly, S. A. Ali, K. Abdel-Hady, Thin Solid Fil 483330 (2005).

20. H. Kamal, E. K. Elmaghraly, S. A. Ali, K. Abdel-Hady, J. Crystal Grow 262424 (2004).

21. Y. Sawada, C. Kobayashi, J. Seki, H. Funakubo, Thin Solid Films 446 (2002).

22. T. Fukano, T. Motohiro, Solar Energy Mater. Solar Cells 825 (2004).

23. A. Reguig, M. Regragui, M. Morsli, A. Khelil, M. Addou, J. C. Berne `Solar Energy Mater. Solar Cells 901381 (2006). 


\section{EPJ Web of Conferences}

24. H. P. Klug, L. E. Alexender, X-ray Diffraction Procedures for Polycrys line and Amorphous Materials, Wiley, New York, 1974.

25. M. Janda, A. Kubovy, Phys. Stat. Sol. A 35391 (1976). 